\title{
Bacterial diversity and potential risk factors associated with Salmonella contamination of seafood products sold in retail markets in Bangkok, Thailand
}

\author{
Edward R. Atwill ${ }^{1}$, Saharuetai Jeamsripong ${ }^{\text {Corresp. } 2}$ \\ ${ }^{1}$ School of Veterinary Medicine, University of California, Davis, Department of Population Health and Reproduction, Davis, CA, USA \\ 2 Research Unit in Microbial Food Safety and Antimicrobial Resistance, Department of Veterinary Public Health, Faculty of Veterinary Science, \\ Chulalongkorn University, Bangkok, Thailand \\ Corresponding Author: Saharuetai Jeamsripong \\ Email address: saharuetai.j@chula.ac.th
}

Consumption of contaminated food causes 600 million cases, including 420,000 of fatal infections every year. Estimated cost from food-borne illnesses is USD 110 billion per year, especially in low- and middle-income countries. Thailand is a leading producer and consumer of seafood, but little is known about bacterial contamination in seafood. In particular, public health agencies need to know the relationship between bacterial diversity in seafood and their risk factors, as assessed with readily available culturedependent and bacterial phenotyping methods. To address this, levels of indicator bacteria, Salmonella and Vibrio in various seafood commodities were determined and to identify risk factors associated with Salmonella contamination. A total of 335 samples were collected from October 2018 to July 2019 throughout Bangkok, Thailand; overall sample composition was Pacific white shrimp ( $n=85)$, oysters $(n=82)$, blood cockles $(n=84)$, and Asian seabass $(n=84)$. The prevalence was $100 \%$ for fecal coliforms and $85 \%$ for $E$. coli. In contrast, prevalence was $59 \%$ for $V$. parahaemolyticus, $49 \%$ for $V$. cholerae, $19 \%$ for $V$. alginolyticus, $18 \%$ for $V$. vulnificus, and $36 \%$ for Salmonella. Highest concentrations of fecal coliforms and $E$. coli were in oysters. Highest concentrations of Salmonella with Matopeni (31\%) being the predominant serotype were in shrimp. Salmonella contamination was significantly associated with type of seafood, sampling location, retail conditions, and the presence of $E$. coli, V. alginolyticus and $V$. vulnificus. A cutoff value for E. coli concentration of $1.3 \times 10^{4} \mathrm{MPN} / \mathrm{g}$ predicted contamination of Salmonella, with a sensitivity of $84 \%$ and specificity of $61 \%$. Displaying seafood products on ice, presence of E. coli and Vibrio, and seafood derived from Eastern Thailand were associated with an increased risk of Salmonella contamination. 
1 Bacterial diversity and potential risk factors associated with

2 Salmonella contamination of seafood products sold in retail

3 markets in Bangkok, Thailand

4

5

6

7

8

\author{
Edward R. Atwill ${ }^{1}$, Saharuetai Jeamsripong ${ }^{2}$
}

${ }^{1}$ Department of Population Health and Reproduction, School of Veterinary Medicine, University of California, Davis, CA, USA

${ }^{2}$ Research Unit in Microbial Food Safety and Antimicrobial Resistance, Department of Veterinary Public Health, Faculty of Veterinary Science, Chulalongkorn University, Bangkok, Thailand

\title{
Corresponding Author:
}

Saharuetai Jeamsripong

Faculty of Veterinary Science, Chulalongkorn University, 39 Henri Dunant Road, Pathumwan, Bangkok 10330, Thailand

Email address: saharuetai.j@gmail.com

\section{Abstract}

Consumption of contaminated food causes 600 million cases, including 420,000 of fatal infections every year. Estimated cost from food-borne illnesses is USD 110 billion per year, especially in low- and middle-income countries. Thailand is a leading producer and consumer of seafood, but little is known about bacterial contamination in seafood. In particular, public health agencies need to know the relationship between bacterial diversity in seafood and their risk factors, as assessed with readily available culture-dependent and bacterial phenotyping methods. To address this, levels of indicator bacteria, Salmonella and Vibrio in various seafood commodities,were determined and-to identify risk factors associated with Salmonella contamination. A total of 335 samples were collected from October 2018 to July 2019 throughout Bangkok, Thailand; overall sample composition was Pacific white shrimp $(\mathrm{n}=85)$, oysters $(n=82)$, blood cockles $(n=84)$, and Asian seabass $(n=84)$. The prevalence was $100 \%$ for fecal coliforms and $85 \%$ for $E$. coli. In contrast, prevalence was $59 \%$ for $V$. parahaemolyticus, $49 \%$ for $V$. cholerae, $19 \%$ for $V$. alginolyticus, $18 \%$ for $V$. vulnificus, and $36 \%$ for Salmonella. Highest concentrations of fecal coliforms and E. coli were in oysters. Highest concentrations of Salmonella with Matopeni (31\%) being the predominant serotype, were in shrimp. Salmonella contamination was significantly associated with type of seafood, sampling location, retail conditions, and the presence of $E$. coli, $V$. alginolyticus and $V$. vulnificus. A cutoff value for $E$. coli concentration of $1.3 \times 10^{4} \mathrm{MPN} / \mathrm{g}$ predicted contamination of Salmonella, with a sensitivity of $84 \%$ and specificity of $61 \%$. Displaying seafood products on ice, presence of $E$. 
39 coli and Vibrio, and seafood derived from Eastern Thailand were associated with an increased 40 risk of Salmonella contamination.

41 


\section{Introduction}

43 The global fisheries and aquaculture both inland and marine reached 171 million tonnes in 2016

44 (Food and Agriculture Organization of the United Nations, 2018) and consumption of fish, and 45 fishery products per capita double from $10 \mathrm{~kg}$ in 1960 to greater than $20 \mathrm{~kg}$ in 2016 (Food and 46 Agriculture Organization of the United Nations, 2018). In Southeast Asia, consumption of fish 47 and fishery products varies from 6 to $64 \mathrm{~kg}$ per capita per year (Food and Agriculture 48 Organization of the United Nations, 2015). In Thailand, consumption of fish and fishery products is about $31 \mathrm{~kg}$ per capita per year, which accounts for $12 \%$ of total protein consumption per person (Food and Agriculture Organization of the United Nations, 2015). Thailand is one of the top ten exporters of fish and fishery products, which accounted for $4 \%$ of global exports in 2016 (Food and Agriculture Organization of the United Nations, 2018).

Due to the rapid growth of global consumption of fish and fishery products, seafood safety is of high public health concern.Foodborne diseases each year afflict a third of the world

55 population $_{\mathbf{A}}$ (World Health Organization, 2004), but data about the number of illnesses from seafood-borne outbreaks is limited for many parts of the world. Most examinations of seafood outbreaks have been done in the United States, where approximately 9.4 million illnesses, almost 56,000 hospitalizations, and 1,351 deaths, were associated with foodborne contamination per year (Scallan et al., 2011). Almost half (45\%) of foodborne outbreaks reported in the U.S. are from bacteria, and fish are frequently implicated (Gould et al., 2013). In Europe, 5,175 foodborne outbreaks were reported in 2019. Salmonella spp. cause most of these outbreaks. There were 87,923 and 7,775 confirmed cases of salmonellosis and infections from Shiga-toxinproducing Escherichia coli, respectively (European Food Safety Authority; European Centre for Disease Prevention and Control, 2021).

Pollution, animal density, and global trading contribute to bacterial contamination of seafood products (Papadopoulou et al., 2007). The most common pathogens associated with seafood-borne diseases are Vibrio, Salmonella, Shigella, and Clostridium botulinum (Iwamoto et al., 2010). Seafood-borne outbreaks caused by V. parahaemolyticus, V. cholera serogroup O139, $V$. vulnificus, Salmonella serotype Weltevreden, and E. coli have been reported (BonninJusserand et al., 2019; Heinitz et al., 2020; Martinez-Urtaza et al., 2016; Raymond \& Ramachandran, 2019).

In Thailand, $V$. parahaemolyticus and Salmonella spp. are the leading causes of foodborne diarrhea. Even though Thailand is one of the major exporters of seafood products, monitoring of bacterial pathogens of these exports is limited. Therefore, the objectives of this study were: 1) examine the prevalence of bacterial indicators, $V$. parahaemolyticus, $V$. cholerae, $V$. vulnificus, $V$. alginolyticus, and Salmonella isolated from Pacific white shrimp, oysters, blood cockle, and Asian seabass in fresh markets in Bangkok, Thailand; 2) identify serotypes of Salmonella among various seafood samples; and 3) determine risk factors for Salmonella contamination and a potential cutoff value for $E$. coli concentration predicting the presence of Salmonella in these samples. 
82 Materials \& Methods

83 Sample collection

84 Samples of fresh fish and shellfish $(n=335)$ were collected from open-air retail fresh markets 85 between October 2018 and July 2019 from four districts in Bangkok, Thailand, resulting in a 86 sample composition of Pacific white shrimp (Litopenaeus vannamei) $(n=85)$, oyster (Saccostrea 87 cuccullata) $(n=82)$, blood cockle (Tegillarca granosa) $(n=84)$, and Asian seabass (Lates 88 calcarifer) $(n=84)$ (Table 1$)$. Due to varying availability of these four different seafood 89 commodities at each market, there were slightly different total sample sizes for some seafood 90 commodities ranging from $n=82$ to $n=85$ (Table 1). Pacific white shrimp, oysters, and blood 91 cockles are raised in saltwater ponds; the majority of Asian seabass are raised in estuaries, but 92 some are raised in saltwater ponds.

93 Individual seafood samples were purchased in the early morning (5 to 7 a.m.). At least $94200 \mathrm{~g}$ of the samples were placed into a double sterile plastic bag. The samples were kept on ice $95\left(<10{ }^{\circ} \mathrm{C}\right)$ during transportation and kept in the cooler. All samples were submitted to the 96 laboratory within $3 \mathrm{~h}$. Microbiological determination was performed within $6 \mathrm{~h}$ after receiving samples in the Department of Veterinary Public Health, Faculty of Veterinary Science, Chulalongkorn University.

Average and standard deviation (sd) of minimum and maximum ambient air temperature $\left({ }^{\circ} \mathrm{C}\right)$, wind speed $(\mathrm{km} / \mathrm{h})$, precipitation $(\mathrm{mm})$, and relative humidity $(\%)$ in Bangkok, Thailand, were retrieved from the Thai Meteorological Department (www.tmd.go.th). The average ( \pm sd) daily minimum and maximum ambient air temperature was $26.8( \pm 1.8){ }^{\circ} \mathrm{C}$ and $34.1( \pm 2.6){ }^{\circ} \mathrm{C}$; average $( \pm \mathrm{sd})$ wind speed was $13.0( \pm 2.0) \mathrm{km} / \mathrm{h}$, average 24-hour precipitation $1.4( \pm 4.0) \mathrm{mm}$, and average relative humidity was $75.1( \pm 7.4) \%$.

106

\section{Predictor variables}

Risk factors for Salmonella contamination included type of seafood (Pacific white shrimp, oyster, blood cockle, or Asian seabass), sampling district (Din Daeng, Huay Kwang, Samphanthawong, or Dusit), regional source of seafood (central, eastern, southern Thailand, or unidentified source), retail storage of fish and shellfish samples (pooling and combining different seafood products for retail display versus keeping each seafood type separate when on display), and retail display condition (on ice or without ice). The concentrations of fecal coliform (MPN/g) and E. coli (MPN/g), and the prevalence of $V$. parahaemolyticus, $V$. vulnificus, $V$. alginolyticus and $V$. cholerae were evaluated as putative risk factors for Salmonella

114 contamination.

\section{Bacterial concentration and phenotyping}

116 Seafood samples were analyzed in triplicate for coliforms, E. coli, Salmonella, $V$. parahaemolyticus, $V$. vulnificus, $V$. alginolyticus and $V$. cholerae. Fecal coliform and $E$. coli were enumerated according to the U.S. Food and Drug Administration (U.S. FDA) Bacteriological Analytical Manual (BAM) with slight modification (Feng et al., 2002). Briefly, a $25 \mathrm{~g}$ sample (shrimp and Asian seabass) was aseptically cut into small pieces and placed into 225 $\mathrm{mL}$ of Buffered Peptone Water (BPW) (Difco, MD, USA). Pieces were then homogenized for 1 
122 to $2 \mathrm{~min}$. The resulting suspension was serially diluted using three-tube most probable number 123 (MPN) at different dilutions from $10^{-1}$ to $10^{-4}$. One $\mathrm{mL}$ of each solution was diluted in Lactose

124

125

126

127

128

129

130

131

132

133

134

135

136

137

138

139

140

141

142

143

144

145

146

147

148

149

150

151

152

153

154

155

156

157

158

159

160

161 Broth (LB) (Difco), and then incubated at $35^{\circ} \mathrm{C}$ for $24 \mathrm{~h}$. A loopful of the mixture solution was transferred to Brilliant Green Lactose Bile (BGLB) (Difco) and EC broth (Difco), respectively. After overnight incubation, positive tubes were recorded and calculated as concentration of fecal coliforms (MPN/g). One loopful of EC broth was streaked on Eosin Methylene Blue (EMB; Difco) agar plates and reported as E. coli concentration (MPN/g).

Fecal coliform and E. coli were enumerated in oysters and blood cockles following (Feng et al., 2002). Briefly, $100 \mathrm{~g}$ of meat was added into $100 \mathrm{~mL}$ of Phosphate Buffered Saline (PBS) (Difco), which was then blended aseptically for 1 to $2 \mathrm{~min}$. The resulting suspension was serially diluted in LB to $10^{-4}$. These dilutions were transferred to BGLB and EC broth. Biochemical tests including indole test and Triple Sugar Iron (TSI; Difco) were performed on suspect colonies for all samples. The lower and upper limits of the detection of fecal coliforms and E. coli were 1.0 and $1.1 \times 10^{5} \mathrm{MPN} / \mathrm{g}$, respectively.

Salmonella detection followed ISO 6579-1:2017 (International Organization for Standardization, 2017). Briefly, $25 \mathrm{~g}$ of seafood was cut, and added to $225 \mathrm{~mL}$ of BPW. The pieces were homogenized for $2 \mathrm{~min}$ and incubated at $37^{\circ} \mathrm{C}$ for $18 \mathrm{~h}$. After incubation, $0.1 \mathrm{~mL}$ of the suspension was inoculated into Modified Semi-solid Rappaport-Vassiliadis (MSRV) (Difco) agar plate and incubated at $42{ }^{\circ} \mathrm{C}$ overnight. A loopful from the MSRV plates was restreaked onto Xylose Lysine Deoxycholate (XLD) (Difco) agar. Presumptive colonies of Salmonella were pink to red colonies with a black center. Biochemical tests (citrate utilization, TSI reaction, indole test) were used to confirm presumptive Salmonella colonies according to a standard protocol from the U.S. FDA BAM (Andrews et al., 2007). Three typical colonies of Salmonella were selected for serotyping. Slide agglutination test was performed to determine serotype of Salmonella followed by Kauffmann-White Scheme, Pasteur Institute (Grimont and Weill, 2007). Commercial antiserums (S\&A Reagents Lab Ltd., Lat Phrao, Bangkok, Thailand) were used to determine the serotype of Salmonella.

Isolation of Vibrio spp. followed U.S. FDA BAM (Kaysner et al., 2004). Briefly, $50 \mathrm{~g}$ of each sample was added to $450 \mathrm{~mL}$ of PBS, and homogenized for 1 to $2 \mathrm{~min}$. One $\mathrm{mL}$ of resulting suspension was added to $10 \mathrm{~mL}$ of Alkaline Peptone Water (APW) (Difco) and incubated at 37 ${ }^{\circ} \mathrm{C}$ overnight. After incubation, one loopful of solution was streaked on Thiosulfate-Citrate-Bile Salts-sucrose (TCBS) (Difco) agar plate containing $2 \%$ of NaCl. Presumptive colonies of Vibrio were confirmed using CHROMagar ${ }^{\mathrm{TM}}$ Vibrio (HiMedia Laboratories, Mumbai, India) agar. TCBS and CHROMagar ${ }^{\mathrm{TM}}$ Vibrio plates were incubated at $37^{\circ} \mathrm{C}$ for $24 \mathrm{~h}$. Colonies with green center on TCBS agar were presumed to be $V$. parahaemolyticus. Colorless colonies were presumed to be $V$. vulnificus. On CHROMagar ${ }^{\mathrm{TM}}$ Vibrio agar plate, mauve colonies were presumed to be $V$. parahaemolyticus, and green blue to turquoise blue were presumed to be of $V$. vulnificus. Colorless colonies were presumed to be $V$. alginolyticus.

Isolation of $V$. cholerae followed U.S. FDA BAM (Kaysner et al., 2004). Briefly, $25 \mathrm{~g}$ of sample was added to $225 \mathrm{~mL}$ of APW, homogenized for 1 to $2 \mathrm{~min}$, and incubated at $35 \pm 2{ }^{\circ} \mathrm{C}$ for 
$1628 \mathrm{~h}$. A loopful of solution was streaked to TCBS agar plates. After incubation at $37{ }^{\circ} \mathrm{C}$ for $24 \mathrm{~h}$,

163

164

165

166

167

168

169

170

171

172

173

174

175

176

177

178

179

180

181

182

183

184

185

186

187

188

189

190

191

192

193

194

195

196

197

198

199

200

201

presumptive colonies of $V$. cholerae were confirmed on CHROMagar ${ }^{\mathrm{TM}}$ Vibrio. Typical colonies of $V$. cholerae on TCBS agar plate are 2 to $3 \mathrm{~mm}$ diameter, yellow, and flat colonies with opaque center, whereas the presumptive colonies of $V$. cholerae in CHROMagar ${ }^{\mathrm{TM}}$ Vibrio agar were green blue to turquoise blue. Biochemical tests including TSI, oxidase test, and growth in sodium chloride were conducted to confirm Vibrio identifications.

\section{Statistical analyses}

Chi-square test and odds ratios were used to examine the association between different species of bacterial contamination and different types of seafood. For the odds ratio calculations of the association between bacteria contamination among seafood samples, shrimp was set as the referent category based on its popularity in Thai cuisine and largest sample size $(n=85)$ of the four seafood commodities. In addition, logistic regression was used to determine the association between Salmonella contamination and various risk factors. To construct the final logistic regression model, univariate associations were first evaluated for all risk factors for Salmonella and an initial multivariable model constructed from only significant univariate risk factors $(P \leq$ 0.2). A backward stepping algorithm was then used to eliminate non-significant $(P>0.05)$ risk factors based on a likelihood ratio test resulting in a final multivariable logistic regression model with only significant $(P \leq 0.05)$ risk factors. Receiver operating characteristic $(\mathrm{ROC})$ analysis was performed to predict contamination of Salmonella using estimation of the concentration of E. coli. Based on ROC analysis, the optimal cutoff value for the concentration of E. coli. was determined. All statistical analyses were performed using Stata version 14.0 (StataCorp, College Station, TX, USA). A $P$-value $<0.05$ was considered as statistically difference under the twosided hypothesis test.

\section{Results}

\section{Occurrence of indicator bacteria in seafood samples}

All seafood products sampled in Bangkok were positive for fecal coliforms with total average concentration $( \pm \mathrm{sd})$ at $9 \times 10^{4}\left( \pm 4 \times 10^{4}\right) \mathrm{MPN} / \mathrm{g}$ (Table 2$)$. The prevalence of $E$. coli was $85 \%$, with total average concentration $( \pm \mathrm{sd})$ of $2 \times 10^{4}\left( \pm 4 \times 10^{4}\right) \mathrm{MPN} / \mathrm{g}$. Oyster samples had the highest concentrations $( \pm \mathrm{sd})$ of fecal coliforms at $1 \times 10^{5}\left( \pm 7 \times 10^{3}\right)$ and E. coli at $5 \times 10^{4}( \pm$ $5 \times 10^{3}$ ), while blood cockle and seabass had the lowest concentrations of these indicator bacteria (Table 2).

\section{Occurrence of Vibrio and Salmonella in seafood samples}

The overall prevalence for the various bacterial pathogens observed in all 335 seafood samples was $59 \%$ for $V$. parahaemolyticus, $18 \%$ for $V$. vulnificus, $19 \%$ for $V$. alginolyticus, $49 \%$ for $V$. cholerae and $36 \%$ for Salmonella. The highest prevalence of $V$. parahaemolyticus, $V$. vulnificus, $V$. alginolyticus, $V$. cholerae, and Salmonella were observed in blood cockle (78\%), Pacific white shrimp (33\%), oyster (29\%), Asian seabass (76\%), and Pacific white shrimp (40\%), respectively (Figure 1). The lowest prevalence $(<10 \%)$ of $V$. vulnificus was observed in blood cockle and for $V$. alginolyticus in Asian seabass. Moreover, shrimp were most likely to have any

Peer] reviewing PDF | (2021:05:61091:3:0:NEW 1 Nov 2021) 
202 of the four pathogens, followed by oysters (Figure 1). Blood cockles exhibited very high

203 contamination of $V$. parahaemolyticus, while Asian seabass tended to harbor $V$. cholerae (Figure

204 1). Based on Chi-square tests, the was a significant association between different types of

205 samples and the occurrence of $V$. parahaemolyticus, $V$. vulnificus, $V$. alginolyticus, $V$. cholerae, 206 and Salmonella contamination $(P<0.0001)$.

207 Pacific white shrimp exhibited a high prevalence of $V$. parahaemolyticus (59\%), $V$. 208 cholerae (53\%) and Salmonella (47\%), whereas oysters were mainly contaminated with $V$. 209 parahaemolyticus (45\%) and Salmonella (38\%). In-blood cockles, they had-low prevalence of $V$. 210 cholerae, $V$. vulnificus, and $V$. alginolyticus. Asian seabass exhibited a high prevalence of $V$. 211 cholerae (91\%) and Salmonella (46\%).

212 Matopeni (31\%), Corvallis (5\%), Give (5\%), and Rissen (5\%) were the most common 213 serotypes of Salmonella isolated from seafood products (Table 3). Matopeni was the

214 predominant serotype (52/56) observed from Asian seabass samples ( $n=56$ isolates), whereas 215 Itami and Leith were common serovars isolated from the shrimp samples ( $n=47$ isolates). For 216 oysters ( $n=43$ isolates) and blood cockles ( $n=24$ isolates), the major serotypes were Give 217 (19\%) and Rissen (33\%), respectively.

218 The distribution of Salmonella, V. parahaemolyticus, $V$. vulnificus, $V$. cholerae, and $V$. 219 alginolyticus among seafood products

220 Odds of $V$. vulnificus contamination in shrimp was $7.0(1 / 0.143)$ times higher than that for blood 221 cockle $(P=0.002)$ (Table 4$)$. Odds of $V$. cholerae contamination in shrimp were $7.5(1 / 0.134)$

222 and $23.6(1 / 0.043)$ times higher than for oyster $(P<0.0001)$ and blood cockle $(P=0.002)$,

223 respectively. The presence of $V$. parahaemolyticus in the blood cockle was higher than in shrimp $224(\mathrm{OR}=9.1, P<0.0001)$. The odds of $V$. alginolyticus contamination in shrimp was $13.3(1 / 0.075)$ 225 and $20.0(1 / 0.050)$ times higher than in blood cockles and seabass, respectively.

226 Risk factors associated with Salmonella contamination

227

228

229

230

231

232

233

234

235

Salmonella contamination of seafood sold throughout Bangkok was significantly associated with type of seafood, sampling district, retail display condition, regional source of seafood, and the presence of E. coli, V. alginolyticus, and $V$. vulnificus (Table 5). Salmonella contamination in Pacific white shrimp was not different form Asian seabass; in contrast, both oysters and blood cockles had significantly lower odds of Salmonella contamination compared to shrimp. Seafood from markets in Huay Kwang $(\mathrm{OR}=1.7)$ and Dusit $(\mathrm{OR}=1.4)$ had a higher odds of Salmonella contamination compared to seafood from Din Daeng and Samphanthawong. Seafood displayed on ice $(\mathrm{OR}=1.7, P<0.0001)$ had a higher odds of Salmonella contamination compared to retail seafood products not displayed on ice. Seafood products sourced from Eastern Thailand had

236

237 significantly higher odds of Salmonella contamination compared to seafood sourced from other

238

239 regions ( $\mathrm{OR}=3.5, P<0.0001)$. Lastly, the odds of Salmonella contamination were positively associated with the presence of $E$. coli and $V$. alginolyticus, but negatively associated with $V$. vulnificus.

240 ROC and area under the ROC curve 
241 The area under the ROC curve (AUC) at $64 \%$ with standard error $=0.30$ (C.I. $=58 \%-70 \%$ )

242 (Figure 2). The ROC AUC was statistically significance $(P<0.0001)$ compared to the null value 243 of AUC $=0.5$. The presence of Salmonella in seafood products was predicted by a concentration 244 of $1.3 \times 10^{4}$ E. coli $\mathrm{MPN} / \mathrm{g}$, with a sensitivity of $84 \%$ and specificity of $61 \%$.

245

\section{Discussion}

247 According to the Ministry of Public Health for Thailand, the concentration of E. coli should not 248 exceed $10 \mathrm{MPN} / \mathrm{g}$ of fresh or frozen seafood and less than $3 \mathrm{MPN} / \mathrm{g}$ of seafood consumed raw; in 249 addition, all products must not contain detectable Salmonella, V. cholerae, $V$. parahaemolyticus 250 in a $25 \mathrm{~g}$ sample (Bureau of Quality and Safety of Food, 2020). In this study, the concentration of $251 E$. coli averaged $2 \times 10^{4} \mathrm{MPN} / \mathrm{g}$ for all the seafood samples. In fact, only $18 \%(n=60 / 335)$ of all 252 seafood samples had concentrations of $E$. coli $<10 \mathrm{MPN} / \mathrm{g}$ and only $7 \%(n=6 / 82)$ of oyster 253 samples (often eaten raw) had $<3 \mathrm{MPN} / \mathrm{g}$. Furthermore, the prevalence of Salmonella (36\%), $V$. 254 cholerae (49\%), V. parahaemolyticus (59\%) indicated widespread bacterial contamination of 255 these seafood products, which also violates food safety standards. Therefore, implementation of 256 basic sanitation and evaluation of microbiological contamination of seafood products sold in 257 Bangkok are needed

258 Salmonella is an important pathogen that is responsible for seafood-borne illness

259

260

261

262

263

264

265

266

267

268

269

270

271

272

273

274

275

276

277

278

279

280 worldwide (Barrett et al., 2017; European Food Safety Authority, 2014). However, Salmonella is not a normal flora in finfish and shellfish products. The major sources of Salmonella contamination in seafood include aquatic and aquaculture systems, seafood processing facilities, hygiene practices during transport, storage, and handling (Amagliani et al., 2012; Fernandes et al., 2018). In this study, the prevalence of Salmonella ranged from $14 \%$ to $47 \%$. This prevalence was similar to the prevalence of $25 \%$ Salmonella contamination of shrimp cultured in Vietnam (Phan et al., 2005), but substantially less than the 90 to $100 \%$ prevalence of Salmonella contamination in fish (93\%) and shrimp (100\%) collected from a market in Indonesia (Pramono et al., 2019).

Type of seafood, sampling retail location, use of ice during retail display, regional source of seafood, and presence of E. coli and Vibrio were all significantly associated with the presence of Salmonella (Table 5). These risk factors should be interpreted with caution given the observational nature of this study and the possibility of undetected confounding in the statistical analysis. The presence of $E$. coli in a seafood sample was associated with a 4-fold increase in the odds of Salmonella contamination ( $\mathrm{OR}=4.0, P<0.0001)$; similarly, the presence of $V$. alginolyticus in a seafood sample was associated with a 1.4-fold increase in the odds of Salmonella contamination $(\mathrm{OR}=1.4, P<0.04)$.

Seafood displayed on ice during retail had almost twice the odds of Salmonella contamination $(\mathrm{OR}=1.7, P<0.0001)$ than seafood not displayed on ice. This may seem counterintuitive, but ice used to chill seafood can be contaminated with pathogenic microorganisms (Falcão et al., 2009). Ice can be a vehicle for various pathogenic organisms, including diarrheagenic E. coli, Aeromonas, S. enteritidis and fecal coliforms (Falcão et al., 
281

282

283

284

285

286

287

288

289

290

291

292

293

294

295

296

297

298

299

300

301

302

303

304

305

306

307

308

309

310

311

312

313

314

315

316

317

318

319

320

2002; Falcão et al., 2004; Kirov, 1993). In this study, most of the ice used to store seafood was at risk of rapidly melting due to high ambient temperatures in open air conditions. Melting ice can spread bacteria from one seafood item to nearby retail items, readily contaminating other seafood left standing in contaminated melt water.

In addition, the physical placement of seafood for display in retail markets can spread bacterial contamination between seafood items if seafood handlers do not practice proper sanitation during handling (i.e., bare hands touching multiple seafood items; not replacing latex or plastic gloves at high enough frequency during retail display placement of seafood items). Therefore, maintaining sanitary conditions during the production, storage, and use of ice to prevent microbial contamination should be closely observed. Implementation of programs for food safety and also for prevention and control of diarrheal diseases have reduced mortality and morbidity rates of diarrheal diseases and strengthened food safety in Thailand (Food Control Division, Food and Drug Administration, Thailand. 2004).

Seafood sourced from Eastern Thailand had a 3.5-higher odds of Salmonella contamination than seafood from other regions $(\mathrm{OR}=3.5, P<0.0001)$. The coastal area of Eastern Thailand has concentrated areas of industrialization, agricultural development, and tourism-related urbanization, with major concerns of increased water pollution and resource depletion (Nitivattananon and Srinonil, 2019). Wastewater quality is a major concern for this area, especially in Chonburi and Rayong Provinces due to several industrial estates. Moreover, Chonburi, Chachoengsao, and Rayong Provinces have been designated for developing the Eastern Economic Corridor (EEC), so reduction of waste and wastewater is of increasing concern.

In this study, the diversity of Salmonella serovars varied between the different seafood products. Pacific white shrimp had the greatest diversity, $21_{\Lambda}$ different serovars with prevalence per serovar ranging from 1-3\%. Eleven serovars from isolated from oysters, with prevalence per serovar ranging from 1-5\% similar to Pacific white shrimp. In contrast, only 5 serovars were isolated from blood cockles, with a similar range of prevalence per serovar of 2-5\%. Least diverse were isolates from Asian seabass where-only two serovars were recovered, with 52 of 56 of these Salmonella isolates being Matopeni and the remainder being Paratyphi B. Serotype Matopeni has been reported in aquatic pet shops (Gaulin et al., 2005) and in food supplements from Germany (European Commission, 2018). The infection of $S$. Matopeni has been reported in Malaysian children (Lee et al., 2003). Salmonella Paratyphi B in raw tuna sushi imported from Indonesia in 2015 caused 65 foodborne cases in the U.S. (Centers for Disease Control and Prevention, 2018). S. Typhimurium, $S$. Enteritidis, $S$. Typhi, and $S$. Paratyphi B were also detected in fresh fish in Iran (Rahimi et al., 2013). S. Paratyphi B can be classified as d-tartrate fermenting $(\mathrm{dT}+)$ and $\mathrm{d}$-tartrate non-fermenting (dT-) strains. The $\mathrm{dT}+$ strain is less virulent and commonly reported with gastroenteritis, while the dT- strain is associated with paratyphoid fever. The $\mathrm{dT}+$ strain is associated with a significant emerging disease worldwide and of public health concern (Denny et al., 2007, Hassan et al., 2018). Hence, classification of $S$. Paratyphi B biotype should be further investigated. 
321

322

323

324

325

326

327

328

329

330

331

332

333

334

335

336

337

338

339

340

341

342

343

344

345

346

347

348

349

350

351

352

353

354

355

356

357

358

359

360

The common serovars in Pacific white shrimp were Itami $(11 \%, n=5 / 47)$ and Leith $(9 \%$, $n=4 / 47)$. Itami was first documented as a new serovar from a traveler to Thailand suffering from gastroenteritis (Sakazaki et al., 1981). Itami has also been reported from infected humans in Taiwan (Kuo et al., 2014). In contrast to serovars isolated during this study, serovars $S$. Weltevreden, $S$. Tennessee, and $S$. Dessau were isolated from shrimp from the Mekong Delta, Vietnam (Phan et al., 2005). The most common S. enterica serovar isolated from oysters was Give (19\%,n=8/43 isolates), which is different from oysters in the U.S. where Newport was the most common serotype (Brands et al., 2005). A previous study in Western Thailand found that the most common serovar in cultured oysters (C. lugubris and C. belcheri) from Phang Nga Province was Paratyphi B (Jeamsripong et al., 2018). This suggests that the distribution of Salmonella serovars within Thailand depends on geographical location and type of seafood. Serovar Give is an enteric serotype usually isolated from swine and ruminants, but rarely found in humans (Higgins et al., 1997). It is possible that the contamination of Give may be the result of livestock or agricultural production near the oyster growing site- $S$. enterica Give has been frequently reported in European national laboratories (Jansen et al., 2005). The higher virulence of the Give serovar compared to other non-typhoidal Salmonella may explain the higher hospital rate associated with human Give infections (Girardin et al., 2006).

Even though typhoid and paratyphoid salmonellosis are endemic diseases in Thailand, typhoid fever rates declined, and paratyphoid stabilized from 2003 to 2014 in this nation (Techasaensiri et al., 2018). In Thailand, S. enterica Weltevreden is commonly reported in human, frozen seafood, frozen ducks, and polluted water (Bangtrakulnonth et al., 2004). S. Weltevreden, $S$. Stanley, $S$. Anatum, and $S$. Rissen are frequently reported in human from northern and central Thailand (Prasertsee et al., 2019; Sirichote et al., 2010). Therefore, surveillance and monitoring of oysters due to this $\sim 20 \%$ prevalence of Salmonella contamination, and fully cooking oysters prior to consumption are both needed to reduce the risk of food-borne Salmonella infection from Thai-cultured oysters.

In this study, the most common Salmonella serovar found in blood cockles was Rissen (33\%, $n=8 / 24$ isolates), similar to a study in India (Kumar et al., 2009), but it should be noted that none of the five different serovars isolated from cockles had a prevalence above $5 \%$. Seafood such as cockles can acquire Salmonella from contaminated water or other environmental matrices during aquaculture, processing, shipping, and retail display. Good hygiene and basic sanitation together with proper seafood handling and storage should be performed throughout the food chain (farm to fork) to reduce the risk of seafood-related Salmonella.

According to BQSF for Thailand seafood for human consumption should have no detectable $V$. parahaemolyticus and $V$. cholerae in $25 \mathrm{~g}$ of sample; however, $50-60 \%$ of samples contained these bacteria. This high prevalence is consistent with previous work demonstrating that between 2003 and 2015 the prevalence of $V$. parahaemolyticus was $64 \%$ in oysters, followed by clams (53\%), fish (51\%), and shrimp (48\%) (Odeyemi, 2016). V. parahaemolyticus, $V$.

cholerae, and $V$. vulnificus are important seafood-borne pathogens that cause gastroenteritis in humans. $V$. alginolyticus can cause ear infection and intestinal disease in humans. In this study, 
361 the main source of $V$. parahaemolyticus was blood cockles (OR $=9.1, P<0.05)$, while $V$.

362 cholerae was commonly found in Asian seabass $(\mathrm{OR}=4.0, P>0.05)$. V. parahaemolyticus and

$363 V$. vulnificus have been reported in bivalves in many countries such as Thailand, China, and

364 Korea (Changchai \& Saunjit, 2014; Jiang et al., 2019; Ryu et al., 2019). In this study, shrimp

365

366

367

368

369

370

371

372

373

374

375

376

377

378

379

380

381

382

383

384

385

386

387

388

389

390

391

392

393

394

395

396

397

398

399

400 and oysters were predominantly contaminated with $V$. vulnificus and $V$. alginolyticus.

Clostridium perfringens, Staphylococcus aureus, V. parahaemolyticus, and Salmonella spp. are the leading causes of foodborne illnesses in Thailand (Bureau of Epidemiology, 2019). In Thailand, human salmonellosis caused 167 illnesses per 100,000 persons in 2019. Contaminated produce and water have been indicated as important sources of Salmonella infection (Bureau of Epidemiology, 2019). The trend of $V$. cholerae infection decreased from 2.51 to 0.02 cases per 100,000 persons during 2010-2019, and contaminated water and seafood, poor sanitation, and dense housing have been blamed as sources of contamination (Bureau of Epidemiology, 2019).

In this study, the determination of bacterial prevalence and abundance was made using culture-dependent methods. For Salmonella spp. and Vibrio spp. detection this approach has high accuracy and sensitivity compared with certain molecular techniques (Almeida et al., 2013; Eriksson \& Aspan 2007; Hara-Kudo et al., 2001; Mainar-Jaime et al., 2013; Yeung \&Thorsen, 2016). However, these methods can fail to detect viable but nonculturable state (VBNC) strains. VBNC bacteria can preserve metabolic activity and generate virulent proteins (Alleron et al., 2013; Morishige et al., 2015). Hence, molecular techniques are recommended to determine bacterial contamination, but unfortunately such equipment, needed supplies and training required to implement these molecular techniques are not readily available to many food safety officers, even in the developed world. In the absence of molecular equipment, the use of an appropriate MPN assay is justified and provides an estimate of bacterial load, along with ease of interpretation of the results. In this study, the determination of bacterial species was made using bacterial phenotyping methods, a culture-based method which was justified given our goals for a highly sensitive assay using readily available reagents which could also estimate the number of culturable bacteria in Bangkok seafood commodities. Identification of specific serogroups of Vibrio spp., virulence factors, and bacterial toxins should be examined in future work.

E. coli concentrations appeared well suited to predicting Salmonella contamination of seafood. Based on the Youden index that uses the maximal difference between sensitivity and 1specificity (Ruopp et al., 2008), a cutoff value for E. coli was $1.3 \times 10^{4} \mathrm{MPN} / \mathrm{g}$ can be implemented for both monitoring seafood for Salmonella contamination and to establish threshold control measures at processing or during retail storage. This cutoff is much higher than the microbiological criteria set forth in the Commission Regulation (EC) No 2073/2005 (European Commission, 2005), and the BQSF, Thailand (Bureau of Quality and Safety of Food, 2020). This may be because high concentrations of $E$. coli in this sample collection generated a high cutoff value to discriminate the presence or absence of Salmonella in the samples. Lastly, given that the detection of Salmonella and Vibrio spp. is of similar expense and technical difficulty as quantifying $E$. coli concentrations in seafood matrices, it may be more expeditious

Peer) reviewing PDF | (2021:05:61091:3:0:NEW 1 Nov 2021) 
401 and more accurate to focus seafood safety monitoring protocols on Salmonella and Vibrio spp.

402 detection rather than rely on indicator bacteria like E. coli that invariably suffer from false-

403 positive and false-negative signals.

404

405

\section{Conclusions}

406

Finfish and shellfish products sold in Bangkok are contaminated with diverse Salmonella

407 serovars and species of Vibrio. Although the concentration of E. coli predicted Salmonella

408 contamination for these seafood samples, the high cutoff value $\left(1.3 \times 10^{4} \mathrm{MPN} / \mathrm{g}\right)$ for maximal

409

410

411

412

413

414

415

416

417

418

419

420

421

422

423

424

425

426

427

428

429

430

431

432

433

434

435

436

437

438

439

440 test accuracy will likely prevent this method from being adopted as a food hygiene surveillance tool. Current Thai BQSF regulations require no more than $10 \mathrm{E}$. coli $\mathrm{MPN} / \mathrm{g}$ for fresh or frozen seafood ${ }_{2}$ Bacterial contamination varied by seafood commodity, with substantial differences between Asian seabass, oysters, blood cockle, and Pacific white shrimp. This may reflect different aquaculturing, harvesting, processing, and retail display practices.

\section{Acknowledgements}

The authors thank Chailai Chareamchainukul, Mullika Kuldee, Varangkana Thaotumpitak, and Saweeyah Toodbat for their technical assistance.

\section{References}

Alleron L, Khemiri A, Koubar M, Lacombe C, Coquet L, Cosette P, Jouenne T, Frere J. 2013. VBNC Legionella pneumophila cells are still able to produce virulence proteins. Water Research 47:6606-6617 DOI 10.1016/j.watres.2013.08.032.

Almeida C, Cerqueira L, Azevedo NF, Vieira MJ. 2013. Detection of Salmonella enterica serovar Enteritidis using real time PCR, immunocapture assay, PNA FISH and standard culture methods in different types of food samples. International Journal of Food Microbiology 161:16-22 DOI 10.1016/j.ijfoodmicro.2012.11.014.

Amagliani G, Brandi G, Schiavano GF. 2012. Incidence and role of Salmonella in seafood safety. Food Research International 45:780-788 DOI 10.1016/j.foodres.2011.06.022.

Andrews WH, Wang H, Jacobson A, Ge B, Zhang G, Hammack T. 2007. Bacteriological Analytical Manual (BAM). Chapter 5: Salmonella. Retrieved February 14, 2021. Available at https://www.fda.gov/food/laboratory-methods-food/bam-chapter-5-salmonella.

Bangtrakulnonth A, Pornreongwong S, Pulsrikarn C, Sawanpanyalert P, Hendriksen RS, Lo Fo Wong DM, Aarestrup FM. 2004. Salmonella serovars from humans and other sources in Thailand, 1993-2002. Emerging Infectious Diseases Journal 10:131-136 DOI 10.3201/eid1001.02-0781

Barrett KA, Nakao, JH, Taylor, EV, Eggers C, Gould LH. 2017. Fish-Associated Foodborne Disease Outbreaks: United States, 1998-2015. Foodborne Pathogens and Disease 14:537543 DOI 10.1089/fpd.2017.2286.

Bonnin-Jusserand M, Copin S, Le Bris C, Brauge T, Gay M, Brisabois A, Grard T, Midelet-Bourdin G. 2019. Vibrio species involved in seafood-borne outbreaks (Vibrio 
441

442

443

444

445

446

447

448

449

450

451

452

453

454

455

456

457

458

459

460

461

462

463

464

465

466

467

468

469

470

471

472

473

474

475

476

477

478

479

480

cholerae, $V$. parahaemolyticus and $V$. vulnificus): Review of microbiological versus recent molecular detection methods in seafood products. Critical Reviews in Food Science and Nutrition 59:597-610 DOI 10.1080/10408398.2017.1384715.

Brands DA, Inman AE, Gerba CP, Maré CJ, Billington SJ, Saif LA, Levine JF, Joens LA. 2005. Prevalence of Salmonella spp. in oysters in the United States. Applied and Environmental Microbiology 71:893-897 DOI 10.1128/AEM.71.2.893-897.2005.

Bureau of Epidemiology. 2019. Annual epidemiological surveillance report 2019. department of disease control, ministry of public health. Retrieved August 2, 2021. Available at https://apps.doe.moph.go.th/boeeng/annual.php.Bureau of Quality and Safety of Food. 2020. Assessment of Microbiological Quality. Retrieved February 14, 2021. Available at http://bqsf.dmsc.moph.go.th.

Centers for Disease Control and Prevention. 2018. Multistate outbreak of Salmonella Paratyphi B variant L(+) tartrate(+) and Salmonella Weltevreden infections linked to frozen raw tuna: USA, March-July 2015 Epidemiology and Infection 146:1461-1467. DOI 10.1017/S0950268818001462.

Changchai N, Saunjit S. 2014. Occurrence of Vibrio parahaemolyticus and Vibrio vulnificus in retail raw oysters from the eastern coast of Thailand. The Southeast Asian Journal of Tropical Medicine and Public Health 45:662-669.

Denny J, Threlfall J, Takkinen J, Löfdahl S, Westrell T, Varela C, Adak B, Boxall N, Ethelberg S, Torpdahl M, Straetemans Masja, van Pelt W. 2007. Multinational Salmonella Paratyphi B variant Java (Salmonella Java) outbreak, August - December 2007. Eurosurveillance 12:pii=3332.

Eriksson E, Aspan A. 2007. Comparison of culture, ELISA and PCR techniques for salmonella detection in faecal samples for cattle, pig and poultry. BMC Veterinary Research 3:21 DOI 10.1186/1746-6148-3-21.

European Commission. 2005. Commission regulation (EC) No 2073/2005 microbiological criteria for foodstuffs. Official Journal of the European Union, 1-26.

European Commission. 2018. Salmonella enterica ser. Matopeni (presence $/ 25 \mathrm{~g}$ ) in food supplement from Germany.

European Food Safety Authority. 2014. The European Union summary report on trends and sources of zoonoses, zoonotic agents and food-borne outbreaks in 2012. EFSA Journal 12:3547 DOI 10.2903/j.efsa.2014.3547.

European Food Safety Authority; European Centre for Disease Prevention and Control. 2021. The European Union One Health 2019 Zoonoses Report. EFSA journal 19:2 e66406. DOI 10.2903/j.efsa.2021.6406.

Falcão JP, Dias AMG, Correa EF, Falcão DP. 2002. Microbiological quality of ice used to refrigerate foods. Food Microbiology 19:269-276 DOI 10.1006/fmic.2002.0490.

Falcão JP, Falcão DP, Gomes TAT. 2004. Ice as a vehicle for diarrheagenic Escherichia coli. International Journal of Food Microbiology 91:99-103 DOI 10.1016/S01681605(03)00327-1.

Peer] reviewing PDF | (2021:05:61091:3:0:NEW 1 Nov 2021) 
481

482

483

484

485

486

487

488

489

490

491

492

493

494

495

496

497

498

499

500

501

502

503

504

505

506

507

508

509

510

511

512

513

514

515

516

517

518

519

520

Feng P, Weagant SD, Grant MA, Burkhardt W, Shellfish M, Water B. 2002. Bacteriological Analytical Manual (BAM): Chapter 4: Enumeration of Escherichia coli and the Coliform Bacteria. Retrieved February 14, 2021. Available at https://www.fda.gov/food/laboratorymethods-food/bam-chapter-4-enumeration-escherichia-coli-and-coliform-bacteria.

Fernandes DVGS, Castro VS, Cunha Neto Ad, Figueiredo EEdS. 2018. Salmonella spp. in the fish production chain: a review. Ciência Rural 48:e20180141 DOI 10.1590/0103$\underline{8478 \mathrm{cr} 20180141 .}$

Food and Agriculture Organization of the United Nations. 2015. The consumption of fish and fish products in the Asia-Pacific region based on household surveys. Retrieved February 14, 2021. Available at http://www.fao.org/publications/card/en/c/ba100e664b37-4a1b-ba2b-364e6a3205bc/.

Food and Agriculture Organization of the United Nations. 2018. The State of World Fisheries and Aquaculture 2018 - Meeting the sustainable development goals. Retrieved February 14, 2021. Available at http://www.fao.org/documents/card/en/c/I9540EN/.

Food Control Division, Food and Drug Administration, Thailand. 2004. FAO/WHO regional conference on food safety for Asia and the Pacific. Country report. Foodborne diseases: situation of diarrheal diseases in Thailand. Retrieved August 2, 2021. Available at http://www.fao.org/3/ad703e/ad703e00.htm.

Gaulin C, Vincent C, Ismail J. 2005. Sporadic infections of Salmonella Paratyphi B, var. Java associated with fish tanks. Canadian Journal of Public Health 96:471-474 DOI 10.1007/BF03405194.

Girardin F, Mezger N, Hächler H, Bovier PA. 2006. Salmonella serovar Give: an unusual pathogen causing splenic abscess. European Journal of Clinical Microbiology and Infectious Diseases 25:272-274.

Gould LH, Walsh KA, Vieira AR, Herman K, Williams IT, Hall AJ, Cole D. 2013. Surveillance for foodborne disease outbreaks - United States, 1998-2008. Morbidity and Mortality Weekly Report: Surveillance Summaries 62:1-34.

Grimont PAD, Weill FX. 2007 Antigenic Formulae of the Salmonella Serovars. $9^{\text {th }}$ Edition, World Health Organization Collaborating Center for Reference and Research on Salmonella, Institute Pasteur, Paris.

Hara-Kudo Y, Nishina T, Nakagawa H, Konuma H, Hasegawa J, Kumagai S. 2001. Improved method for detection of Vibrio parahaemolyticus in Seafood. Applied and Environmental Microbiology 67:5819-5823 DOI 10.1128/AEM.67.12.5819-5823.2001.

Hassan R, Tecle S, Adcock B, Kellis M, Weiss J, Saupe A, Sorenson A, Klos R, Blankenship J, Blessington T, Whitlock L, Carleton HA, Concepción-Acevedo J, Tolar B, Wise M, Neil KP. 2018. Multistate outbreak of Salmonella Paratyphi B variant L $(+)$ tartrate $(+)$ and Salmonella Weltevreden infections linked to imported frozen raw tuna: USA, March-July 2015. Epidemiology and infection 146:1461-1467 DOI 10.1017/S0950268818001462.

Heinitz ML, Ruble R, Wagner DE, Tatini S. 2000. Incidence of Salmonella in fish and seafood. Journal of Food Protection 63:579-592 DOI 10.4315/0362-028X-63.5.579.

Peer] reviewing PDF | (2021:05:61091:3:0:NEW 1 Nov 2021) 
521

522

523

524

525

526

527

528

529

530

531

532

533

534

535

536

537

538

539

540

541

542

543

544

545

546

547

548

549

550

551

552

553

554

555

556

557

558

559

Higgins R, Désilets A, Cantin M, Messier S, Khakhria R, Ismaïl J, Mulvey MR, Daignault D, Caron H. 1997. Outbreak of Salmonella give in the province of Quebec. The Canadian Veterinary Journal 38:780-781.

International Organization for Standardization. 2017. Microbiology of the food chain Horizontal method for the detection, enumeration and serotyping of Salmonella - Part 1: Detection of Salmonella spp. (ISO Standard No. 6579-1: 2017).

Iwamoto M, Ayers T, Mahon BE, Swerdlow DL. 2010. Epidemiology of seafood-associated infections in the United States. Clinical Microbiology Reviews 23:399-411 DOI 10.1128/CMR.00059-09.

Jansen A, Frank C, Prager R, Oppermann H, Stark K. 2005. Nation-wide outbreak of Salmonella Give in Germany, 2004. Z Gastroenterol 43:707-713 DOI 10.1055/s-2005$\underline{858256 .}$.

Jeamsripong S, Chuanchuen R, Atwill ER. 2018. Assessment of Bacterial Accumulation and Environmental Factors in Sentinel Oysters and Estuarine Water Quality from the Phang Nga Estuary Area in Thailand. International Journal of Environmental Research and Public Health 15:1970 DOI 10.3390/ijerph15091970.

Jiang Y, Chu Y, Xie G, Li F, Wang L, Huang J, Zhai Y, Yao L. 2019. Antimicrobial resistance, virulence and genetic relationship of Vibrio parahaemolyticus in seafood from coasts of Bohai Sea and Yellow Sea, China. International Journal of Food Microbiology 290:116-124 DOI 10.1016/j.ijfoodmicro.2018.10.005.

Kaysner CA, DePaola A, Jones J. 2004. Bacteriological Analytical Manual (BAM): chapter 9: Vibrio. Retrieved February 14, 2021. Available at https://www.fda.gov/food/laboratorymethods-food/bam-chapter-9-vibrio.

Kirov SM.1993. The public health significance of Aeromonas spp. in foods. International Journal of Food Microbiology 20:179-198 DOI 10.1016/0168-1605(93)90164-c.

Kumar R, Surendran PK, Thampuran N. 2009. Distribution and genotypic characterization of Salmonella serovars isolated from tropical seafood of Cochin, India. Journal of Applied Microbiology 106:515-524 DOI 10.1111/j.1365-2672.2008.04020.x.

Kuo HC, Lauderdale TL, Lo DY, Chen CL, Chen PC, Liang SY, Kuo JC, Liao YS, Liao CH, Tsao CS, Chiou CS. 2014. An association of genotypes and antimicrobial resistance patterns among Salmonella isolates from pigs and humans in Taiwan. PLoS One 9:e95772 DOI 10.1371/journal.pone.0095772.

Lee WS, Puthucheary SD, Parasakthi N, Choo KE. 2003. Antimicrobial susceptibility and distribution of non-typhoidal Salmonella serovars isolated in Malaysian children. Journal of tropical pediatrics 49:37-41.

Mainar-Jaime RC, Andrés S, Vico JP, San Román B, Garrido V, Grilló MJ. 2013. Sensitivity of the ISO 6579:2002/Amd 1:2007 standard method for detection of Salmonella spp. on mesenteric lymph nodes from slaughter pigs. Journal of clinical microbiology 51: 89-94 DOI 10.1128/JCM.02099-12.

Peer] reviewing PDF | (2021:05:61091:3:0:NEW 1 Nov 2021) 
560

561

562

563

564

565

566

567

568

569

570

571

572

573

574

575

576

577

578

579

580

581

582

583

584

585

586

587

588

589

590

591

592

593

594

595

596

597

598

599

Martinez-Urtaza J, Powell A, Jansa J, Rey JL, Montero OP, Campello MG, López MJ, Pousa A, Valles MJ, Trinanes J, Hervio-Heath D, Keay W, Bayley A, Hartnell R, Baker-Austin C. 2016. Epidemiological investigation of a foodborne outbreak in Spain associated with U.S. West Coast genotypes of Vibrio parahaemolyticus. SpringerPlus 5:18 DOI 10.1186/s40064-016-1728-1.

Morishige Y, Fujimori K, Amano F. 2015. Use of flow cytometry for quantitative analysis of metabolism of VBNC (Viable But Non-Culturable) Salmonella. Biological and Pharmaceutical Bulletin b15-00005 DOI 10.1248/bpb.b15-00005.

Phan TT, Khai LT, Ogasawara N, Tam NT, Okatani AT, Akiba M, Hayashidani H. 2005. Contamination of Salmonella in retail meats and shrimps in the Mekong Delta, Vietnam. Journal of Food Protection 68:1077-1080 DOI 10.4315/0362-028x-68.5.1077.

Prasertsee T, Chokesajjawatee N, Santiyanont P, Chuammitri P, Deeudom M, Tadee P, Patchanee P. 2019. Quantification and rep-PCR characterization of Salmonella spp. in retail meats and hospital patients in Northern Thailand. Zoonoses Public Health 66:301309 DOI 10.1111/zph. 12565.

Nitivattananon V, Srinonil S. 2019. Enhancing coastal areas governance for sustainable tourism in the context of urbanization and climate change in eastern Thailand. Advances in Climate Change Research 10:47-58 DOI 10.1016/j.accre.2019.03.003.

Odeyemi OA. 2016. Incidence and prevalence of Vibrio parahaemolyticus in seafood: a systematic review and meta-analysis. SpringerPlus 5:464 DOI 10.1186/s40064-016-2115$\underline{7}$.

Papadopoulou C, Economou E, Zakas G, Salamoura C, Dontorou C, Apostolou J. 2007. Microbiological and pathogenic contaminants of seafood in Greece. Journal of Food Quality 30:28-42 DOI 10.1111/j.1745-4557.2007.00104.x.

Pramono H, Kurniawan A, Andika N, Putra TF, Hazwin MAR, Utari S, Kurniawan AP, Masithah ED, Sahidu AM. 2019. Detection of antibiotic-resistant Salmonella sp. in the seafood products of Surabaya local market. IOP Conference Series: Earth and Environmental Science 236:012115.

Rahimi E, Shakerian A, Falavarjani AG. 2013. Prevalence and antimicrobial resistance of Salmonella isolated from fish, shrimp, lobster, and crab in Iran. Comparative Clinical Pathology 22:59-62 DOI 10.1007/s00580-011-1368-3.

Raymond A, Ramachandran A. 2019. Bacterial Pathogens in Seafood-Indian Scenario. Fishery Technology 56:1-22.

Ruopp MD, Perkins NJ, Whitcomb BW, Schisterman EF. 2008. Youden Index and optimal cut-point estimated from observations affected by a lower limit of detection. Biometrical Journal 50:419-430 DOI 10.1002/bimj.200710415.

Ryu AR, Mok JS, Lee DE, Kwon JY, Park K. 2019. Occurrence, virulence, and antimicrobial resistance of Vibrio parahaemolyticus isolated from bivalve shellfish farms along the southern coast of Korea. Environmental Science and Pollution Research 26:21034-21043 DOI 10.1007/s11356-019-05426-1. 
600 Sakazaki R, Tamura K, Abe H, Ogawa Y, Miyata Y. 1981. A new Salmonella serovar:

601

602

603

604

605

606

607

608

609

610

611

612

613

614

615

616

617

618 Salmonella itami (9,12:1,z13:1,2). Japanese Journal of Medical Science and Biology 34:179-180 DOI 10.7883/yoken1952.34.179.

Scallan E, Hoekstra RM, Angulo FJ, Tauxe RV, Widdowson MA, Roy SL, Jones JL, Griffin PM. 2011. Foodborne illness acquired in the United States-major pathogens. Emerging Infectious Diseases Journal 17:7-15 DOI 10.3201/eid1701.P11101.

Sirichote P, Bangtrakulnonth A, Tianmanee K, Unahalekhaka A, Oulai A, Chittaphithakchai P, Kheowrod W, Hendriksen RS. 2010. Serotypes and antimicrobial resistance of Salmonella enterica ssp in central Thailand, 2001-2006. The Southeast Asian Journal of Tropical Medicine and Public 41:1405-15.

Techasaensiri C, Radhakrishnan A, Als D, Thisyakorn U. 2018. Typhoidal Salmonella Trends in Thailand. American Journal of Tropical Medicine and Hygiene 99:64-71 DOI 10.4269/ajtmh.18-0046.

World Health Organization. 2004. Food safety at risk in Asia and the Pacific. Retrieved February 14, 2021. Available at https://apps.who.int/mediacentre/news/releases/2004/pr34/en/index.html.

Yeung M, Thorsen T. 2016. Development of a more sensitive and specific chromogenic agar medium for the detection of Vibrio parahaemolyticus and other Vibrio species. Journal of visualized experiments 117: 54493 DOI 10.3791/54493. 


\section{Table $\mathbf{1}$ (on next page)}

Factors associated with bacterial contamination of seafood products sold in Bangkok, Thailand.

${ }^{1}$ Row totals of percentages may not add to $100 \%$ during to rounding of decimals. 
1 TABLE 1 Factors associated with bacterial contamination of seafood products sold in Bangkok, 2 Thailand.

\begin{tabular}{|c|c|c|c|c|c|}
\hline \multirow[b]{2}{*}{ Risk factors } & \multicolumn{5}{|c|}{ No. of sample $(\%)^{1}$} \\
\hline & $\begin{array}{l}\text { Pacific } \\
\text { white } \\
\text { shrimp }\end{array}$ & Oyster & $\begin{array}{l}\text { Blood } \\
\text { cockle }\end{array}$ & $\begin{array}{c}\text { Asian } \\
\text { seabass }\end{array}$ & Total \\
\hline Type of seafood & $85(25.4 \%)$ & $82(24.5 \%)$ & $84(25.1 \%)$ & $84(25.1 \%)$ & $335(100 \%)$ \\
\hline \multicolumn{6}{|l|}{ Sampling district } \\
\hline Din Daeng & $11(30.6 \%)$ & $7(19.4 \%)$ & $4(11.1 \%)$ & $14(38.9 \%)$ & $36(100 \%)$ \\
\hline Huay Kwang & $17(22.4 \%)$ & $21(27.6 \%)$ & $24(31.6 \%)$ & $14(18.4 \%)$ & $76(100 \%)$ \\
\hline Samphanthawong & $28(25.5 \%)$ & $26(23.6 \%)$ & $28(25.5 \%)$ & $28(25.5 \%)$ & $110(100 \%)$ \\
\hline Dusit & $29(25.7 \%)$ & $28(24.8 \%)$ & $28(24.8 \%)$ & $28(24.8 \%)$ & $113(100 \%)$ \\
\hline \multicolumn{6}{|l|}{$\begin{array}{l}\text { Regional source of } \\
\text { seafood }\end{array}$} \\
\hline Central & $65(25.3 \%)$ & $53(20.6 \%)$ & $72(28.0 \%)$ & $60(26.1 \%)$ & $257(100 \%)$ \\
\hline Eastern & $3(10.7 \%)$ & $0(0 \%)$ & $16(57.1 \%)$ & $9(32.1 \%)$ & $28(100 \%)$ \\
\hline Southern & $10(40.0 \%)$ & $6(24.0 \%)$ & $5(20.0 \%)$ & $4(16.0 \%)$ & $25(100 \%)$ \\
\hline Unidentified & $7(28.0 \%)$ & $7(28.0 \%)$ & $7(28.0 \%)$ & $4(16.0 \%)$ & $25(100 \%)$ \\
\hline \multicolumn{6}{|l|}{ Retail storage } \\
\hline Pool & $4(4.9 \%)$ & $0(0 \%)$ & $0(0 \%)$ & $78(95.1 \%)$ & $82(100 \%)$ \\
\hline Separate & $81(32.0 \%)$ & $82(32.4 \%)$ & $84(33.2 \%)$ & $6(2.4 \%)$ & $253(100 \%)$ \\
\hline \multicolumn{6}{|l|}{$\begin{array}{l}\text { Retail display } \\
\text { condition }\end{array}$} \\
\hline Without ice & $39(31.2 \%)$ & $28(22.4 \%)$ & $47(37.6 \%)$ & $11(8.8 \%)$ & $125(100 \%)$ \\
\hline On ice & $46(21.9 \%)$ & $54(25.7 \%)$ & $37(17.6 \%)$ & $73(34.8 \%)$ & $210(100 \%)$ \\
\hline
\end{tabular}

1 Row totals of percentages may not add to $100 \%$ during to rounding of decimals. 
Table 2 (on next page)

Concentrations of fecal coliforms and E. coli in seafood products sold in Bangkok, Thailand.

Notes sd, standard deviation. 
1 TABLE 2 Concentrations of fecal coliforms and E. coli in seafood products sold in Bangkok, 2 Thailand.

\begin{tabular}{lcccc}
\hline & \multicolumn{2}{c}{ Fecal coliforms } & \multicolumn{2}{c}{ coli } \\
\cline { 2 - 5 } \multicolumn{1}{c}{ Samples } & $\begin{array}{c}\text { Prevalence } \\
(\%)\end{array}$ & $\begin{array}{c}\text { Average } \pm \text { sd } \\
(\text { MPN/g) }\end{array}$ & $\begin{array}{c}\text { Prevalence } \\
(\%)\end{array}$ & $\begin{array}{c}\text { Average } \pm \text { sd } \\
(\mathbf{M P N} / \mathbf{g})\end{array}$ \\
\hline Shrimp $(n=85)$ & $85(100 \%)$ & $9.43 \times 10^{4}\left(3.4 \times 10^{4}\right)$ & $85(100 \%)$ & $1.07 \times 10^{4}\left(2.5 \times 10^{4}\right)$ \\
Oyster $(n=82)$ & $82(100 \%)$ & $1.10 \times 10^{5}\left(7.1 \times 10^{3}\right)$ & $82(100 \%)$ & $5.13 \times 10^{4}\left(4.5 \times 10^{3}\right)$ \\
Blood cockle $(n=84)$ & $84(100 \%)$ & $5.71 \times 10^{4}\left(4.8 \times 10^{4}\right)$ & $68(81.0 \%)$ & $5.85 \times 10^{3}\left(2.2 \times 10^{4}\right)$ \\
Asian seabass $(n=84)$ & $84(100 \%)$ & $8.70 \times 10^{4}\left(4.1 \times 10^{4}\right)$ & $56(66.7 \%)$ & $1.30 \times 10^{3}\left(2.6 \times 10^{3}\right)$ \\
Total $(n=335)$ & $335(100 \%)$ & $8.70 \times 10^{4}\left(4.1 \times 10^{4}\right)$ & $285(85.1 \%)$ & $1.85 \times 10^{4}\left(3.7 \times 10^{4}\right)$ \\
\hline
\end{tabular}

3

4 Notes

5 sd, standard deviation. 


\section{Table 3 (on next page)}

Distribution of Salmonella serovars in seafood products sold in Bangkok, Thailand $(n=$ 170 isolates). 
1 TABLE 3 Distribution of Salmonella serovars in seafood products sold in Bangkok, Thailand ( $n$ $2=170$ isolates).

\begin{tabular}{|c|c|c|c|c|c|}
\hline \multirow[b]{2}{*}{ Serotype } & \multicolumn{5}{|c|}{ Number of positive (\%) } \\
\hline & Shrimp & Oyster & $\begin{array}{l}\text { Blood } \\
\text { cockle }\end{array}$ & $\begin{array}{c}\text { Asian } \\
\text { seabass }\end{array}$ & Total \\
\hline Agona & - & - & $4(2.35)$ & - & $4(2.35)$ \\
\hline Aminatu & $2(1.18)$ & - & - & - & $2(1.18)$ \\
\hline Australia & $1(0.59)$ & - & - & - & $1(0.59)$ \\
\hline Bardo & - & $4(2.35)$ & - & - & $4(2.35)$ \\
\hline Bonames & $3(1.76)$ & - & - & - & $3(1.76)$ \\
\hline Breukelen II & - & $4(2.35)$ & - & - & $4(2.35)$ \\
\hline Corvallis & - & $4(2.35)$ & $4(2.35)$ & - & $8(4.71)$ \\
\hline Dabou & - & $4(2.35)$ & - & - & $4(2.35)$ \\
\hline Dresden & $1(0.59)$ & - & - & - & $1(0.59)$ \\
\hline Enteritidis & $3(1.76)$ & - & - & - & $3(1.76)$ \\
\hline Farmingdale & - & $4(2.35)$ & - & - & $4(2.35)$ \\
\hline Give & - & $8(4.71)$ & - & - & $8(4.71)$ \\
\hline Glidji & - & $2(1.18)$ & - & - & $2(1.18)$ \\
\hline Hisingen & $2(1.18)$ & - & - & - & $2(1.18)$ \\
\hline Itami & $5(2.94)$ & - & - & - & $5(2.94)$ \\
\hline Kentucky & $3(1.76)$ & - & - & - & $3(1.76)$ \\
\hline Konongo & $1(0.59)$ & - & - & - & $1(0.59)$ \\
\hline Lansing & $1(0.59)$ & - & - & - & $1(0.59)$ \\
\hline Leith & $4(2.35)$ & - & - & - & $4(2.35)$ \\
\hline Lexington & - & $4(2.35)$ & - & - & $4(2.35)$ \\
\hline Lezennes & - & - & $4(2.35)$ & - & $4(2.35)$ \\
\hline Linguere & $2(1.18)$ & - & - & - & $2(1.18)$ \\
\hline Matopeni & - & - & - & $52(30.59)$ & $52(30.59)$ \\
\hline Oslo & $3(1.76)$ & - & - & - & $3(1.76)$ \\
\hline Paratyphi B2 & - & - & - & $4(2.35)$ & $4(2.35)$ \\
\hline Rissen & - & - & $8(4.71)$ & - & $8(4.71)$ \\
\hline Ruiru & - & $4(2.35)$ & - & - & $4(2.35)$ \\
\hline Stanley & - & - & $4(2.35)$ & - & $4(2.35)$ \\
\hline Stuttgart & $2(1.18)$ & - & - & - & $2(1.18)$ \\
\hline Soerenga & - & $1(0.59)$ & - & - & $1(0.59)$ \\
\hline Tounouma & $1(0.59)$ & - & - & - & $1(0.59)$ \\
\hline Typhimurium & $1(0.59)$ & - & - & - & $1(0.59)$ \\
\hline Victoria & $3(1.76)$ & - & - & - & $3(1.76)$ \\
\hline Windermere & $3(1.76)$ & - & - & - & $3(1.76)$ \\
\hline Weltevreden & - & $4(2.35)$ & - & - & $4(2.35)$ \\
\hline
\end{tabular}




\begin{tabular}{llllll} 
Wohlen & $2(1.18)$ & - & - & - & $2(1.18)$ \\
Yeerongpilly & $1(0.59)$ & - & - & - & $1(0.59)$ \\
II/IIIa/IV & $3(1.76)$ & - & - & - & $3(1.76)$ \\
Total & $47(27.65)$ & $43(25.29)$ & $24(14.12)$ & $56(32.94)$ & $170(100.00)$ \\
\hline
\end{tabular}

3 


\section{Table 4(on next page)}

Comparing the odds of contamination from Salmonella, $V$. parahaemolyticus, $V$. vulnificus, V. cholerae, or V. alginolyticus among seafood products sold in Bangkok, Thailand.

Notes. ${ }^{1}$ referent category, based on shrimp's popularity in Thai cuisine and largest sample size among the four seafood commodities. OR, Odds ratio. S.E., standard error. C.I., confidence interval. 
1 TABLE 4 Comparing the odds of contamination from Salmonella, $V$. parahaemolyticus, $V$.

2 vulnificus, $V$. cholerae, or $V$. alginolyticus among seafood products sold in Bangkok, Thailand.

\begin{tabular}{|c|c|c|c|c|}
\hline Parameters & OR & S.E. & 95\% C.I. & $P$-value \\
\hline \multicolumn{5}{|l|}{ Salmonella } \\
\hline Shrimp ${ }^{1}$ & 1.0 & - & - & - \\
\hline Oyster & 0.684 & 0.155 & $0.439-1.065$ & 0.093 \\
\hline Blood cockle & 0.188 & 0.388 & $0.125-0.281$ & $<0.0001$ \\
\hline Asian seabass & 0.975 & 0.767 & $0.209-4.555$ & 0.974 \\
\hline Constant & 0.889 & 0.394 & $0.373-2.121$ & 0.791 \\
\hline \multicolumn{5}{|c|}{ V. parahaemolyticus } \\
\hline Shrimp ${ }^{1}$ & 1.0 & - & - & - \\
\hline Oyster & 0.576 & 0.096 & $0.413-0.802$ & 0.001 \\
\hline Blood cockle & 9.100 & 1.686 & $6.329-13.085$ & $<0.0001$ \\
\hline Asian seabass & 0.431 & 0.276 & $0.122-1.515$ & 0.189 \\
\hline Constant & 1.429 & 0.277 & $0.977-2.088$ & 0.065 \\
\hline \multicolumn{5}{|l|}{ V. vulnificus } \\
\hline Shrimp ${ }^{1}$ & 1.0 & - & - & - \\
\hline Oyster & 0.353 & 0.196 & $0.119-1.045$ & 0.060 \\
\hline Blood cockle & 0.143 & 0.088 & $0.043-0.477$ & 0.002 \\
\hline Asian seabass & 0.100 & 0.130 & $0.008-1.285$ & 0.077 \\
\hline Constant & 0.635 & 0.325 & $0.233-1.731$ & 0.374 \\
\hline \multicolumn{5}{|l|}{ V. cholerae } \\
\hline Shrimp ${ }^{1}$ & 1.0 & - & - & - \\
\hline Oyster & 0.134 & 0.060 & $0.056-0.322$ & $<0.0001$ \\
\hline Blood cockle & 0.043 & 0.045 & $0.006-0.329$ & 0.002 \\
\hline Asian seabass & 3.958 & 5.020 & $0.329-47.548$ & 0.278 \\
\hline Constant & 2.400 & 1.596 & $0.652-8.835$ & 0.188 \\
\hline \multicolumn{5}{|l|}{ V. alginolyticus } \\
\hline Shrimp & 1.0 & - & - & - \\
\hline Oyster ${ }^{1}$ & 1.114 & 0.418 & $0.534-2.322$ & 0.774 \\
\hline Blood cockle & 0.075 & 0.087 & $0.008-0.715$ & 0.024 \\
\hline Asian seabass & 0.050 & 0.042 & $0.009-0.260$ & $<0.0001$ \\
\hline Constant & 0.491 & 0.131 & $0.292-0.827$ & 0.007 \\
\hline
\end{tabular}

3

Notes.

$4 \quad{ }^{1}$ referent category, based on shrimp's popularity in Thai cuisine and largest sample size 5 among the four seafood commodities. OR, Odds ratio. S.E., standard error. C.I., confidence 6 interval. 


\section{Table 5(on next page)}

Final multivariable logistic regression model for risk factors associated with Salmonella contamination of seafood products sold in Bangkok, Thailand.

$\mathrm{AIC}=368.67$

Notes. ${ }^{1}$ reference group. OR, Odds ratio. S.E., standard error. C.I., confidence interval. AIC, Akaike information criterion. 
1 TABLE 5 Final multivariable logistic regression model for risk factors associated with

2 Salmonella contamination of seafood products sold in Bangkok, Thailand.

\begin{tabular}{|c|c|c|c|c|}
\hline Parameters & OR & S.E. & 95\% C.I. & $P$-value \\
\hline \multicolumn{5}{|l|}{ Type of seafood } \\
\hline Shrimp ${ }^{1}$ & 1.0 & - & - & - \\
\hline Oyster & 0.48 & 0.089 & $0.331-0.689$ & $<0.0001$ \\
\hline Blood cockle & 0.19 & 0.045 & $0.119-0.303$ & $<0.0001$ \\
\hline Asian seabass & 1.06 & 0.638 & $0.328-3.450$ & 0.919 \\
\hline \multicolumn{5}{|l|}{ Sampling district } \\
\hline Din Daeng ${ }^{1}$ & 1.0 & - & - & - \\
\hline Huay Kwang & 1.66 & 0.232 & $1.259-2.182$ & $<0.0001$ \\
\hline Samphanthawong & 0.43 & 0.046 & $0.351-0.532$ & $<0.0001$ \\
\hline Dusit & 1.42 & 0.120 & $1.205-1.676$ & $<0.0001$ \\
\hline \multicolumn{5}{|c|}{ Retail display condition } \\
\hline No ice ${ }^{1}$ & 1.0 & - & - & - \\
\hline On ice & 1.71 & 0.201 & $1.360-2.154$ & $<0.0001$ \\
\hline \multicolumn{5}{|c|}{ Regional source of seafood } \\
\hline Central $^{1}$ & 1.0 & - & - & - \\
\hline Eastern & 3.46 & 0.670 & $2.325-5.141$ & $<0.0001$ \\
\hline Southern & 0.89 & 0.061 & $0.780-1.020$ & 0.094 \\
\hline Unidentified & 0.81 & 0.135 & $0.581-1.120$ & 0.199 \\
\hline \multicolumn{5}{|l|}{ Presence of $E$. coli } \\
\hline $\mathrm{No}^{1}$ & 1.0 & - & - & - \\
\hline Yes & 4.02 & 1.223 & $2.213-7.295$ & $<0.0001$ \\
\hline \multicolumn{5}{|c|}{ Presence of $V$. alginolyticus } \\
\hline $\mathrm{No}^{1}$ & 1.0 & - & - & - \\
\hline Yes & 1.37 & 0.212 & $1.008-1.851$ & 0.044 \\
\hline \multicolumn{5}{|c|}{ Presence of $V$. vulnificus } \\
\hline $\mathrm{No}^{1}$ & 1.0 & - & - & - \\
\hline Yes & 0.61 & 0.130 & $0.405-0.930$ & 0.021 \\
\hline Constant & 0.19 & 0.051 & $0.109-0.318$ & $<0.0001$ \\
\hline
\end{tabular}

4 Notes.

$5{ }^{1}$ reference group. OR, Odds ratio. S.E., standard error. C.I., confidence interval. AIC, Akaike

6 information criterion. 
Figure 1

The prevalence of $V$. parahaemolyticus (VP), $V$. vulnificus (VV), $V$. alginolyticus (VA), $V$. cholerae (VC), and Salmonella spp. in shrimp $(n=85)$, oyster $(n=82)$, blood cockle ( $n$ $=84)$, and

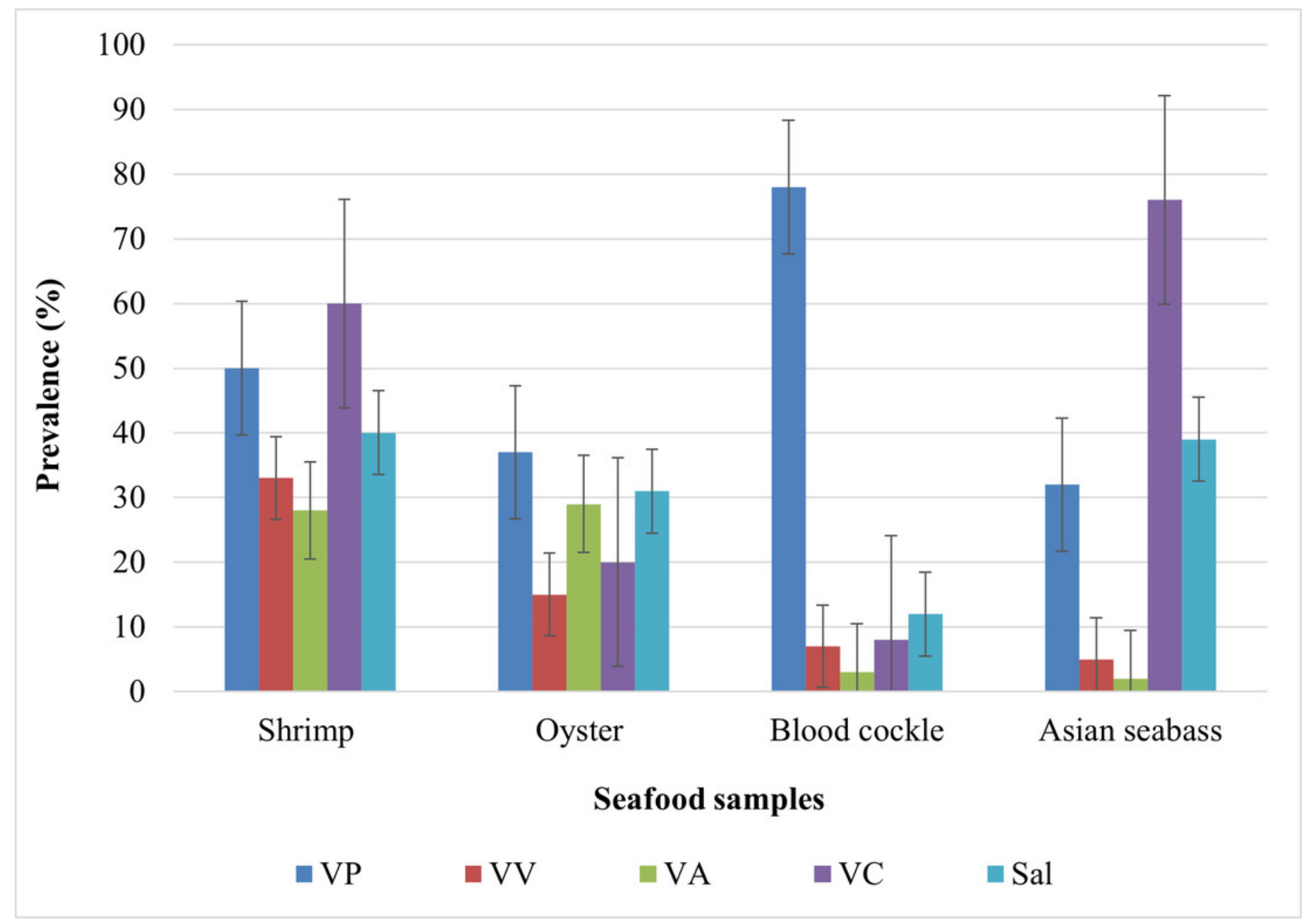


Figure 2

Area under the ROC curve and cutoff value for concentration of $E$. coli were used to maximally predict the contamination of Salmonella in retail seafood commodities $(n=$ 335).

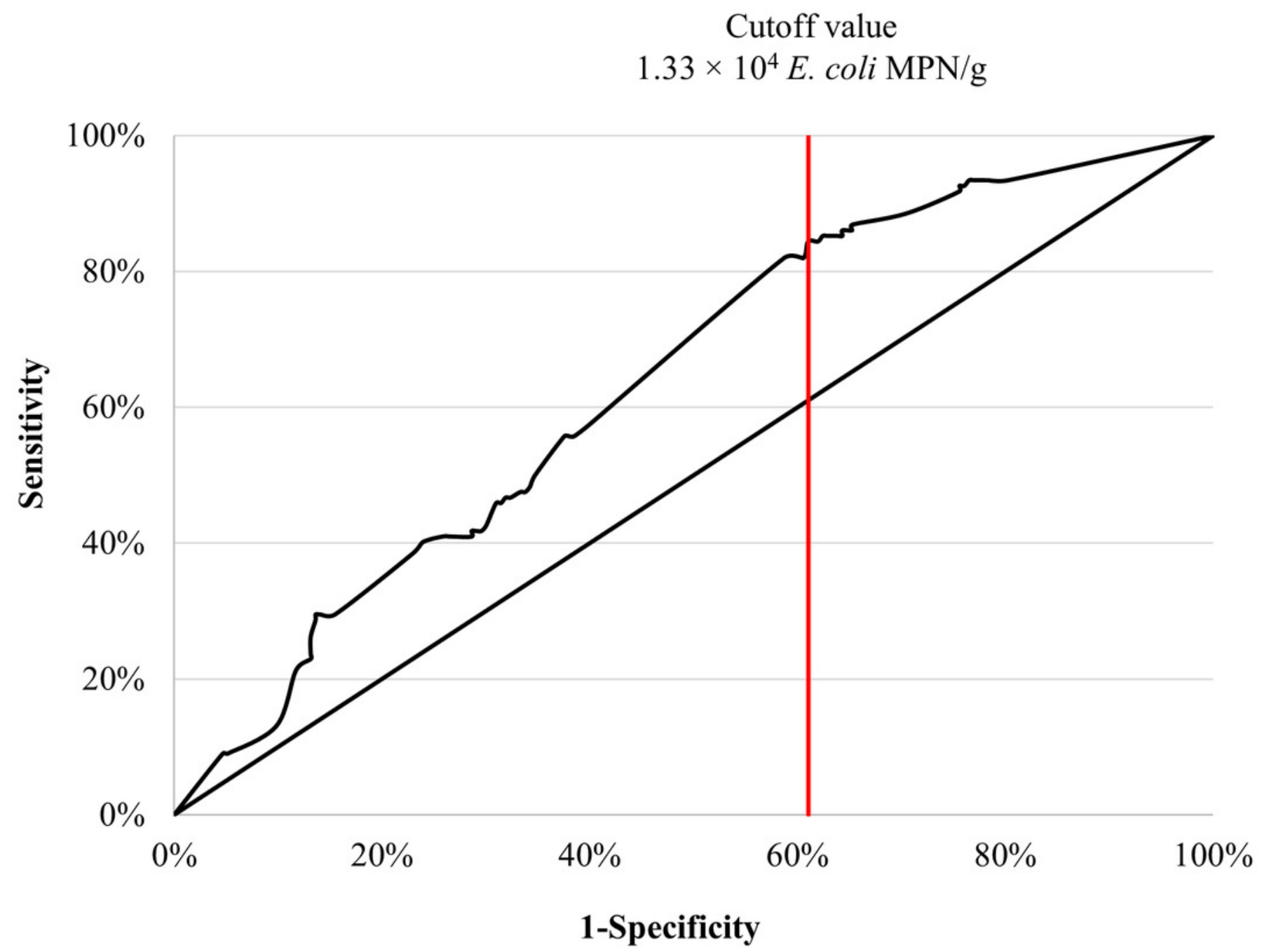

